\title{
Tomato Pathogenesis-related Protein Genes are Expressed in Response to Trialeurodes vaporariorum and Bemisia tabaci Biotype B Feeding
}

\author{
David P. Puthoff • Frances M. Holzer • \\ Thomas M. Perring $\cdot$ Linda L. Walling
}

Received: 14 May 2010/Revised: 10 August 2010 /Accepted: 20 September 2010/Published online: 7 October 2010

(C) The Author(s) 2010. This article is published with open access at Springerlink.com

\begin{abstract}
The temporal and spatial expression of tomato wound- and defense-response genes to Bemisia tabaci biotype B (the silverleaf whitefly) and Trialeurodes vaporariorum (the greenhouse whitefly) feeding were characterized. Both species of whiteflies evoked similar changes in tomato gene expression. The levels of RNAs for the methyl jasmonic acid (MeJA)- or ethylene-regulated genes that encode the basic $\beta$-1,3-glucanase $(G l u B)$, basic chitinase (Chi9), and Pathogenesis-related protein-1 (PR-1) were monitored. GluB and Chi9 RNAs were abundant in infested leaves from the time nymphs initiated feeding (day 5). In addition, $G l u B$ RNAs accumulated in apical non-infested leaves. $P R-1$ RNAs also accumulated after whitefly feeding. In contrast, the ethylene- and salicylic acid (SA)regulated Chi3 and $P R-4$ genes had RNAs that accumulated at low levels and GluAC RNAs that were undetectable in whitefly-infested tomato leaves. The changes in Phenylalanine ammonia lyase5 (PAL5) were variable; in some, but not all infestations, PAL5 RNAs increased in response to whitefly feeding. PAL5 RNA levels increased in response to MeJA, ethylene, and abscisic acid, and declined in response to SA. Transcripts from the wound-response genes, leucine
\end{abstract}

D. P. Puthoff

Department of Biology, Frostburg State University,

Frostburg, MD 21532, USA

\section{F. M. Holzer $\cdot$ L. L. Walling $(\square)$}

Department of Botany and Plant Sciences,

Center for Plant Cell Biology and Center for Disease-Vector

Research, University of California,

Riverside, CA 92521, USA

e-mail: linda.walling@ucr.edu

T. M. Perring

Department of Entomology, University of California, Riverside, CA 92521, USA aminopeptidase (LapA1) and proteinase inhibitor 2 (pin2), were not detected following whitefly feeding. Furthermore, whitefly infestation of transgenic LapA1:GUS tomato plants showed that whitefly feeding did not activate the LapA1 promoter, although crushing of the leaf lamina increased GUS activity up to 40 fold. These studies indicate that tomato plants perceive $B$. tabaci and T. vaporariorum in a manner similar to baterical pathogens and distinct from tissue-damaging insects.

Key Words Bemisia tabaci - Bemisia argentifolii . Trialeurodes vaporariorum $\cdot$ Herbivory $\cdot$ Whitefly . Phloem-feeding $\cdot$ Defense-response $\cdot$ Wound-response . Pathogenesis related-protein genes $\cdot$ Plant-insect interactions

\section{Introduction}

To survive and adapt to their native surroundings, plants have developed mechanisms that detect and rapidly respond to assaults by both pathogens and arthropods. Plants recognize the plant-derived chemical, electrical, and hydraulic signals associated with wounding, as well as the chemical signals that are introduced by herbivore saliva, midgut regurgitant, and oviposition fluid (Felton and Tumlinson, 2008; Howe and Jander, 2008; Fatouros et al., 2009; Walling, 2009; Wu and Baldwin, 2009). Plants perceive the duration, quantity, and quality of these chemical and mechanical signals, and use these "infestation-alert" cues to induce resistance traits that act directly to antagonize insect settling, growth and development, and indirectly by synthesizing and releasing volatiles to attract natural enemies. These defenses limit damage by the plant's attacker, stimulate defenses to counter future attacks, 
preserve vegetative growth and reproduction, yet minimize fitness costs to the plant (Koornneef and Pieterse, 2008; Dicke and Baldwin, 2010; Heil, 2010; Mooney et al., 2010). These complex biochemical and physiological responses are dynamic and often result in a local or systemic resistance to further challenge (De Vos et al., 2006; De Vos and Jander, 2009).

Plants deploy defense-signaling pathways regulated by salicylic acid (SA), jasmonic acid (JA), ethylene, and reactive oxygen species (ROS) in response to herbivores and pathogens (Glazebrook, 2005; Walling, 2009). These pathways are interconnected and can act antagonistically, additively, or synergistically (Mur et al., 2006). The convergence of these pathways at key signaling nodes (NPR1, WRKY70, and glutaredoxin) may enable prioritization of the signaling pathways allowing deployment of the most effective local and systemic defenses against an intruder (Koornneef and Pieterse, 2008). In addition, these defense pathways communicate with abscisic acid (ABA), auxin, gibberellic acid, and brassinosteroid signaling pathways to coordinate the magnitude and quality of the defense response activated (López et al., 2008; Spoel and Dong, 2008). There is accumulating evidence for additional defense-signaling pathways that are modulated after herbivore attack; however the identities of these pathways have yet to be revealed (van de Ven et al., 2000; Glazebrook, 2005; De Vos et al., 2006; De Vos and Jander, 2009; Bhattarai et al., 2010).

Plant defense responses to insects in the order Hempitera are distinct, as these insects use their stylets and salivary secretions in disparate manners to recover nutrients from their host plants. For example, mirid bugs, pyrrhocorids, lygaeids, planthoppers, and leafhoppers are destructive, since they lacerate cells, solubilize cell contents, and consume the cellular slurry (Miles, 1999; Walling, 2009). At the cellular level, these Hemiptera can be as damaging as caterpillars or beetles that cut and tear foliage. At the other end of the spectrum are aphids and whiteflies (Tjallingii, 2006; Walling, 2008). Aphids will puncture numerous mesophyll cells in their search for phloem sieve elements, while whiteflies rarely damage cells on their stylet's path to the phloem.

Over 1,555 whitefly species have been described, although most studies have focused on polyphagous whiteflies, such as the Bemisia tabaci species complex and Trialeurodes vaporariorum (Westwood), that interfere with agricultural and horticultural productivity (De Barro et al., 2005; Martin and Mound, 2007). Trialeurodes vaporariorum is a common pest of greenhouses worldwide and fields in temperate climates, while B. tabaci (Gennadius) biotype B, also known as Bemisia argentifolii (Bellows and Perring), is more widespread, destructive, and invasive (van Lenteren and Noldus, 1990; Inbar and Gerling, 2008). The success of $B$. tabaci biotype B likely is due to a variety of strategies including: ability to adapt to a wide range of plant habitats, broad host range, voracious feeding that may allow it to infest plants with phloem sap of different nutritional values, increased fecundity, breeding strategies that promote invasiveness, and rapid emergence of insecticide-resistant strains (Liu et al., 2007; Inbar and Gerling, 2008; Walling, 2008).

The destructiveness of B. tabaci biotype B is correlated with depletion of photosynthates, deposition of large amounts of excreta (honeydew) that supports sooty mold growth, and its ability to vector over 111 virus species (Inbar and Gerling, 2008). In addition, this whitefly causes plant developmental disorders that can contribute to agricultural losses including tomato fruit irregular ripening and the curcurbit leaf-silvering disorder, the characteristic used in the common name of this biotype (the silverleaf whitefly) (Schuster et al., 1990; De Barro and Khan, 2007). Recently, two newly identified biotypes (MS, Ug6) also were shown to cause silvering, thus demonstrating that this trait has been acquired several times (Delatte et al., 2005; Sseruwagi et al., 2005).

Several studies have evaluated the response of crop and model plants to $B$. tabaci feeding. In the model plant Arabidopsis thaliana (L. Heynh), Bemisia tabaci biotype B causes a profound reprogramming of gene expression (Kempema et al., 2007). B. tabaci causes increases in SAregulated pathogenesis-related $(P R)$ protein gene transcripts and decline in JA-regulated defense RNAs in infested leaves (locally) and systemically in apical, non-infested leaves (Zarate et al., 2007). Use of defense-response mutants and transgenic lines that alter the activity of the SA- and JAregulated defense-signaling pathways (coil, nprl, cevl, cim10, and NahG) and methyl jasmonate (MeJA) treatments show that B. tabaci induces decoy defenses (Zarate et al., 2007). The suppressed JA-regulated defense pathway, not the induced SA-regulated defense pathway, controls the resistance traits that retard nymph development.

The role of the JA, SA, and ethylene defense-signaling pathways in regulating the expression of the resistance traits in crop plants that deter B. tabaci nymph development is less well characterized. Studies in squash show that plants can discriminate the elicitors/effectors (chemical signals) introduced by two different $B$. tabaci biotypes (van de Ven et al., 2000). SLW1 (a M20b peptidase-like gene) and SLW3 (a leaf-specific $\beta$-glucosidase-like gene) RNAs accumulate preferentially in response to $B$. tabaci biotype B feeding but not B. tabaci biotype A. Both $S L W 1$ and SLW3 appear to be regulated by SA-independent pathways (van de Ven et al., 2000). SLW1 RNAs accumulate after JA and ethylene treatments, while $S L W 3$ transcripts do not accumulate in response to known defense signals.

Changes in peroxidase, chitinase, and $\beta$-1,3-glucanase activities have been noted after $B$. tabaci infestations of 
cassava, squash, and tomato (Jiménez et al., 1995; Mayer et al., 1996; Antony and Palaniswami, 2006). In addition, $B$. tabaci biotype B infestation of Phaseolus vulgaris (L.) causes the release of volatiles that are recognized by its parasitoid Encarsia formosa (Gahan) (Birkett et al., 2003). However, in cotton, no changes in volatile bouquets were detected (Rodriguez-Saona et al., 2003). The levels of two pathogenesis-related $(P R)$ protein gene RNAs (PR69B and P6) are known to accumulate during $B$. tabaci biotype B infestation (Sánchez-Hernández et al., 2006). Furthermore, 244 differentially regulated genes were identified using spotted cDNA arrays after B. tabaci infestation of tomato (Estrada-Hernandez et al., 2009).

Given the ability of plants to discriminate between $B$. tabaci biotypes, Macrosiphum. euphorbiae (Thomas) biotypes, and Tetranychus urticae (Koch) lines (van de Ven et al., 2000; Hebert et al., 2007; Kant et al., 2008), it was of interest to develop a more comprehensive understanding of the changes in plant defense-response gene expression in response to two species of whiteflies with distinctive host ranges and abilities to induce developmental disorders and vector viruses. To this end, the temporal and spatial expression of nine tomato genes that respond to wound/ defense signals, including systemin, JA, ethylene, ABA, and SA, were monitored after feeding by $B$. tabaci biotype B or $T$. vaporariorum. In addition, the roles of wound signals in the tomato-Bemisia interaction were investigated using a transgenic tomato line expressing a LapA1:GUS (Leucine aminopepetideA1: $\beta$-glucuronidase) reporter gene construct, which is a sensitive monitor for wounding.

\section{Methods and Materials}

Plant Growth, Insect Colonies and Whitefly Infestations Tomato plants (Solanum lycopersicum cv. Rutgers and cv. Pto238R) were grown in UC Soil Mix III in a growth chamber at $25^{\circ} \mathrm{C}$ with a $16 / 8$-h L:D. At planting, soil was supplemented with osmocote. At $4 \mathrm{wk}$, tomato plants were transferred to insect cages in the greenhouse. Plants were fertilized once per week with Miracle-Gro. Seven-wk-old plants (cv. Rutgers) were used for the temporal and spatial RNA studies. These plants had 15 leaves, and leaves were numbered beginning at the base of the plant. Greenhouse temperatures averaged $29^{\circ} \mathrm{C}$ (day) and $16^{\circ} \mathrm{C}$ (night). Silverleaf whitefly [B. tabaci (Gennadius) biotype B; also known as Bemisia argentifolii (Bellows and Perring)] and greenhouse whitefly [Trialeurodes vaporariorum (Westwood)] colonies were raised on Phaseolus vulgaris (L.) plants. Bemisia tabaci cultures were assayed periodically for isozyme variants to ensure culture purity.

When plants were 7-wk old, the 7th and 8th leaves were encased individually in nylon-mesh bags, and 250 white- flies adults (200 females and 50 males) were placed inside each bag. Control plants were encased in a similar manner, except no insects were added (bagged control; Control B). A second set of control plants was neither bagged nor infested to assess the impact of bagging on wound- and defense-response gene expression (unbagged control; Control U). After $9 \mathrm{~d}$ of feeding, adult whiteflies were removed by aspiration, and the infested tomato leaves (leaves 7 and 8 ) and apical, non-infested leaves (leaf 9) were harvested directly in liquid nitrogen. In time-course experiments, infested and control leaves were harvested at 0, 1, 3, 5, 7, and $9 \mathrm{~d}$ post infestation. Experiments were repeated once and in each experiment each sample was a pool of leaves from three different plants. This infestation protocol resulted in ca. 2,000 nymphs per leaf. Similar nymph densities have been noted in field-grown tomatoes (Gusmão et al., 2006).

Excised shoots from 3- to 4-wk-old tomato (Peto 238R) plants were treated with $10 \mu \mathrm{M}$ MeJA (24 hr), $100 \mu \mathrm{M}$ ABA (24 hr), 29 ppm ethylene (24 hr), 1 pmol systemin (12 hr), or $0.1,0.25$ or $0.5 \mathrm{mM}$ salicylic acid (24 hr). Treatments and controls have been described previously (Gu et al., 1996; Chao et al., 1999).

RNA Extractions and RNA Blot Hybridizations Leaves $(2.5 \mathrm{~g})$ were ground to a fine powder in liquid $\mathrm{N}_{2}$. After $\mathrm{N}_{2}$ evaporation, $5 \mathrm{ml}$ extraction buffer $(100 \mathrm{mM} \mathrm{LiCl}, 100 \mathrm{mM}$ Tris-HCl, $\mathrm{pH} 8.0,10 \mathrm{mM}$ EDTA, $1 \% \mathrm{SDS})$ at $80^{\circ} \mathrm{C}$ and $5 \mathrm{ml}$ of water-saturated phenol $\left(80^{\circ} \mathrm{C}\right)$ were added. After vortexing for $30 \mathrm{sec}, 6 \mathrm{ml}$ chloroform:isoamyl alcohol $(24: 1)$ were added. The sample was vortexed for $30 \mathrm{sec}$ and centrifuged at $3,200 \times g$ at $4^{\circ} \mathrm{C}$ for $60 \mathrm{~min}$. The aqueous layer was removed and mixed with one volume of $4 \mathrm{M}$ $\mathrm{LiCl}$. After $1 \mathrm{hr}$ at $-80^{\circ} \mathrm{C}$, total RNA was recovered by centrifugation at $3,200 \times \mathrm{g}$ at $4^{\circ} \mathrm{C}$ for $60 \mathrm{~min}$, washed with $70 \% \mathrm{EtOH}$, resuspended in water, and stored at $-80^{\circ} \mathrm{C}$.

Total RNAs $(15 \mu \mathrm{g})$ were size fractionated on $1.0 \%$ formaldehyde-agarose gels, blotted to nylon membranes (Hybond-N, Amersham, Piscataway, NJ, USA), hybridized with ${ }^{32} \mathrm{P}$-labeled probes, and washed under conditions of high stringency as described in Pautot et al. (1991). RNA blots for the whitefly infestation experiments were used once to assure maximum sensitivity. RNA blots with defense chemical treatments were reused once. Probes were labeled using $\left[{ }^{32} \mathrm{P}\right]$-dCTP (Amersham). Autoradiographic signals were quantitated using a phosphoimager (Molecular Dynamics).

The PR-1 (P6 protein, pP6), PR-4 (P2 protein, pPR-P2), Chi3 (acidic chitinase, pChi3), Chi9 (basic chitinase, pChi9), GluB (basic $\beta$-1,3-glucanase, pGluBAS), and GluAC (acidic $\beta$-1,3-glucanase, pGluAC) cDNA clones were provided by Dr. Pierre de Wit (Wageningen Agricultural University, Wageningen, The Netherlands) (van Kan et al., 1995). The proteinase inhibitor 2 (pin2; pT2-47) cDNA clone was provided by Dr. C.A. Ryan (Washington 
State University, Pullman, WA, USA) (Graham et al., 1985). The LapA1 partial cDNA clone (pDR57) was previously described (Pautot et al., 1993). There are two genes (LapA1 and LapA2) encoding LAP-A that are 98\% identical at the nucleotide level (Gu et al., 1996); transcripts for both genes are detected under the hybridization conditions utilized. The PAL gene family in tomato (cv. Craigella) consists of 26 family members (Chang et al., 2008). RNAs for only two PAL genes (PAL1 and PAL5) have been detected in tomato (Lee et al., 1992). The PAL1 RNA is not abundant, whereas the PAL5 RNA accumulates during development and in response to abiotic and biotic stresses (Chang et al., 2008). The tomato PAL5 cDNA clone pPal1-16 was $1.6 \mathrm{~kb}$ in length and was isolated as a whitefly-induced cDNA by using differential RNA display from cv Rutgers (D.P. Puthoff and L.L. Walling, unpublished results). Partial sequence of this clone showed 97\% nucleotide identity with PAL5 of tomato cv. BonnyBest (Accession P26600) (Lee et al., 1992).

GUS Histochemical and Fluorometric Assays The LapA1: GUS line U78 was characterized previously (Chao et al., 1999). Homozygous LapA1:GUS or UC82b (wild-type control; WT) tomato plants were planted per 1-gallon pot ( 2 plants/pot) and grown in the greenhouse in insect cages. At $3 \mathrm{wk}$, pots were encased in nylon mesh bags, and plants were infested with $100 \mathrm{~B}$. tabaci biotype B or served as non-infested controls. After $21 \mathrm{~d}$ of infestation, second, third and early fourth instar nymphs were feeding on the abaxial leaf surfaces. At this time, developmentally matched leaves from the control and infested plants were harvested for GUS staining. Leaves from 6-wk-old control (WT) and LapA1:GUS plants grown in insect-free cages were wounded by pricking the abaxial surface of leaflets with a straight pin. Pin pricks were administered to reflect the density of feeding whitefly nymphs $\left(10\right.$ pricks per $\left.\mathrm{cm}^{2}\right)$. Six-wk-old control (WT) and LapA1:GUS plants were mechanically wounded by crushing of the leaf lamina as previously described Chao et al. (1999). Pin-pricked and crushed leaves, as well as developmentally matched leaves from non-damaged WT (control) and LapAl:GUS plants, were harvested $24 \mathrm{hr}$ later. All tissues were stored at $-80^{\circ} \mathrm{C}$ until use.

Extraction and measurement of GUS activity in leaves was according to Jefferson (1987) with the following modifications. Leaves were ground to a fine powder in liquid nitrogen, and $30 \mathrm{mg}$ of tissue were homogenized in GUS extraction buffer $\left(50 \mathrm{mM} \mathrm{NaPO}_{4}, \mathrm{pH} 7.0,10 \mathrm{mM} \beta\right.$ mercaptoethanol, $10 \mathrm{mM}$ EDTA, $0.1 \%$ sodium lauryl sarcosine, $0.1 \%$ Triton X-100). Extracts $(10 \mu \mathrm{l})$ were assayed in a $500-\mu 1$ reaction with GUS assay buffer (2 mM 4-methylumbelliferyl- $\beta$-D-glucuronide in GUS Extraction Buffer) with $20 \%(\mathrm{v} / \mathrm{v})$ methanol to reduce endogenous GUS activity (Kosuge et al., 1990). After 0, 30 , and $60 \mathrm{~min}, 100-\mu \mathrm{l}$ aliquots were removed and added to $1.9 \mathrm{ml} 0.2 \mathrm{M} \mathrm{Na}_{2} \mathrm{CO}_{3}$. Methlyumbelliferone (MU) concentrations were determined by using a Dyna Quant 200 fluorimeter using MU standards. Each plant extract was assayed in triplicate. Protein concentrations were determined with the bicinchoninic acid (BCA) assay (Pierce, Rockford, IL, USA) using bovine serum albumin standards. Protein samples were pretreated with $0.1 \mathrm{M}$ iodoacetamide in $0.1 \mathrm{mM}$ Tris- $\mathrm{HCl}(\mathrm{pH} 8.0)$ at $37^{\circ} \mathrm{C}$ for $20 \mathrm{~min}$ prior to the BCA assay to reduce interference caused by $\beta$ mercaptoethanol (Hill and Straka, 1988).

For GUS histochemical staining, 3-wk-old, greenhousegrown LapA1:GUS tomato seedlings were infested or wounded. Infested plants were monitored for appearance of first, second, and third instar nymphs. Feeding sites of immature insects in each instar were evaluated on at least three different plants after $20 \mathrm{~d}$ of feeding. Infested leaves were harvested and stained for GUS activity (Jefferson, 1987). In brief, tomato leaves were harvested into GUS staining buffer $\left(100 \mathrm{mM} \mathrm{NaPO}, 0.5 \mathrm{mM} \mathrm{K} 3\left[\mathrm{Fe}\left(\mathrm{CN}_{6}\right)\right]\right.$, $0.5 \mathrm{mM} \mathrm{K}_{4}\left[\mathrm{Fe}\left(\mathrm{CN}_{6}\right)\right], 10 \mathrm{mM}$ EDTA, $0.5 \mathrm{mg} / \mathrm{ml} \mathrm{X}$-gluc, $0.1 \%$ Triton X-100, 20\% methanol). X-gluc (5-bromo-4chloro-3-indoyl $\beta$-D-glucuronic acid) was purchased from Research Products International (Mt. Prospect, IL, USA). After vacuum infiltration for $5 \mathrm{~min}$ at $20-25 \mathrm{~mm} \mathrm{Hg}$, tissue was incubated at $37^{\circ} \mathrm{C}$ overnight. Tomato leaves were cleared with repeated changes of $95 \%$ ethanol and viewed in a dissecting scope. While Arabidopsis gene-trap lines demonstrated that the GUS histochemical assay was working (data not shown), GUS activities were not detected histochemically in infested or wounded LapA1:GUS plants. Increasing infiltration times, increasing number of 5-min infiltrations, pretreating leaves by dipping in hexane for $10 \mathrm{sec}$ to $1 \mathrm{~min}$, or performing GUS staining reactions in the presence of $1 \%-4 \%$ DMSO or $0.05 \%-0.5 \%$ Silwet (a wetting agent) did not enhance histochemical detection of GUS activity in the mature LapA1:GUS leaves.

\section{Results}

Whiteflies Do Not Increase Levels of LapA or pin2 $R N A s$ Whiteflies do not cause extensive damage to plant tissues since their stylets follow an intercellular path to reach phloem sieve elements. Therefore, it was important to determine if (a) the occasional epidermal cell piercing, (b) passage of the whitefly stylet through the leaf cell's extracellular matrix, and (c) the puncturing of phloem elements would be perceived as a wound response in tomato. To this end, the levels of RNAs for two wellstudied wound-response genes-leucine aminopeptidase (LapA) and proteinase inhibitor 2 (pin2) - were used as 
Fig. 1 Changes in $L a p A$, pin2, and $P A L$ gene expression after whitefly feeding. A Leaves 7 and 8 of 8 -wk-old tomato plants were infested with 250 adult Besimia tabaci biotype B (Bt) or Trialeurodes vaporariorum $(T v)$. Leaves from non-infested control plants $(C)$ were encased in nylon-mesh bags but no insects were added. After $9 \mathrm{~d}$ of infestation, adult whiteflies were removed and infested leaves and apical, non-infested leaves (leaf 9) were harvested. Total RNAs isolated and RNA blots $(15 \mu \mathrm{g} /$ lane $)$ were hybridized with ${ }^{32} \mathrm{P}$-labeled probes for leucine aminopeptidase (LapA), proteinase inhibitor 2 (pin2), and phenylalanine ammonia lyase $(P A L)$. Film exposure times were $3(P A L)$ or $6(L a p A$, pin2) days. B Plants were infested with $B$. tabaci biotype B (Bt) or T. vaporariorum $(T v)$ as described in Panel A. Infested and apical, non-infested leaves were harvested $0,1,3,5,7$, and $9 \mathrm{~d}$ after infestation. Leaves from control plants that had leaves 7 and 8 encased in insect bags (Control B) and untreated plants (Control $\mathrm{U})$ were harvested at $0,1,3,5,7$, and $9 \mathrm{~d}$. Total RNA blots were hybridized with a ${ }^{32} \mathrm{P}$-labeled $P A L$ probe. Exposure times were $24 \mathrm{hr}$. Stained gels visualizing rRNAs are shown as a loading controls. Results from infested leaf 7 and apical leaf 9 are displayed (A,B). Infested leaf 8 was also analyzed and results were similar to that of leaf 7 (data not shown)

sentinels to monitor the activation of the tomato woundsignaling pathway.

The 7th and 8th leaves of 8-wk-old tomato plants were enclosed in fine-mesh nylon bags and each leaf was infested with 250 adult whiteflies/leaf (4 females: 1 male). To control for possible responses to the inadvertent mechanical damage that occurred during the infestation procedures and plant handling, two sets of controls were included. Some control plants had their leaves encased in nylon bags but insects were not added (Control B). A second set of control plants were not bagged or infested (Control U). The levels of LapA and pin2 RNAs were determined in the infested and apical non-infested leaves at $0,1,3,5,7$, and 9 days after whitefly infestation (Fig. 1A).

Throughout the 9-day infestation, adults fed, mated, and oviposited. During the first 3 days of infestation, only whitefly adults were feeding (500 per plant). During this period, no increases in LapA or pin2 RNAs were detected (data not shown). Between days 3 and 5, eggs began to hatch and firstinstar nymphs established feeding sites. The numbers of feeding nymphs increased over the 9-day period. At the time of harvest, there were approximately 2,000 immature insects and 250 adult insects associated with each infested tomato leaf. Most nymphs were in their second and third instars. Despite the large numbers of whitefly nymphs (10 nymphs $/ \mathrm{cm}^{2}$ leaf area), neither the LapA nor pin2 transcripts were detected in the infested leaves at 9 days post infestation (Fig. 1A) or at earlier times (data not shown).

Since many wound-response genes are expressed systemically and local and systemic responses can be distinct, the levels of LapA and pin2 RNAs in apical, non-infested leaves were determined. LapA and pin2 RNAs were not detected in apical leaves from control or infested plants after 9 days (Fig. 1A) or at earlier times (data not shown). This is in sharp contrast to the rapid increase in LapA or
$A$

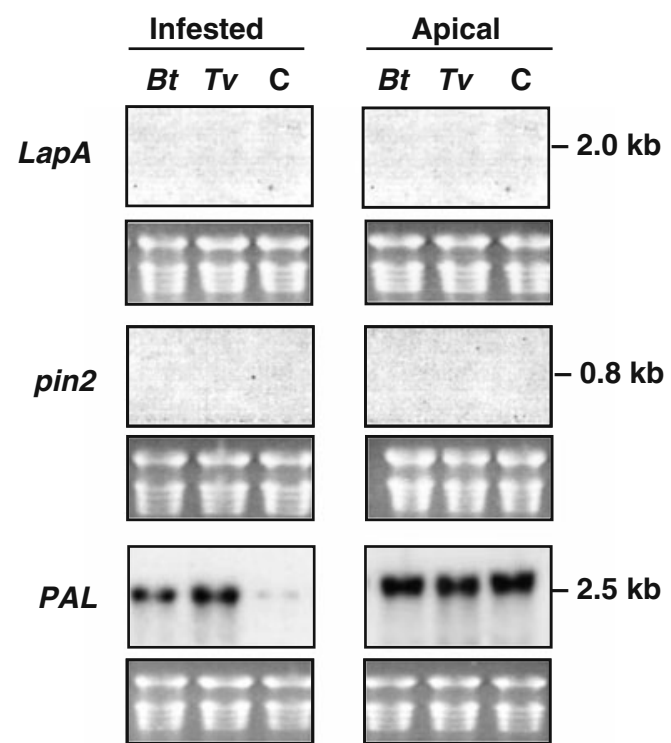

B
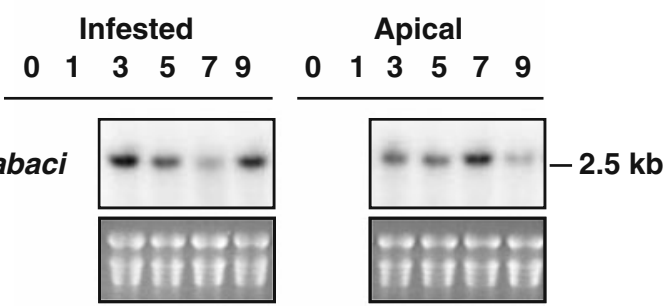

T. vaporariorum
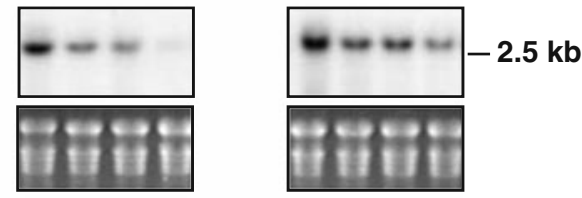

Control B
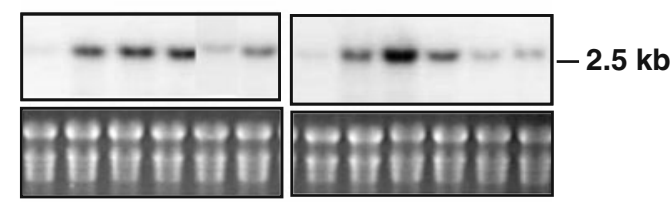

Control U
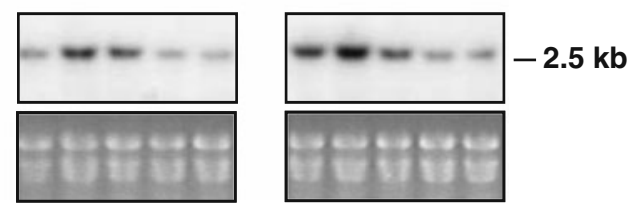

pin 2 mRNA levels that have been previously reported after mechanical wounding or caterpillar feeding (Pautot et al., 1993; Howe et al., 1996).

Although visual damage is not observed after whitefly feeding, wound-response genes (LapA and pin2) might be expressed in a subset of leaf cells (i.e., the epidermal cells that were pierced), and RNA signals may be diluted by the majority of non-responding cells. For this reason, it was of interest to determine if wound-response genes were activated in leaf cells immediately surrounding the stylet path or at the whitefly feeding sites. To this end, transgenic tomato plants expressing the wound-activated LapAl gene 
promoter fused to the $\beta$-glucuronidase (GUS) coding region (LapA1:GUS) were used in whitefly infestation studies. Due to the exceptional stability of GUS in plant cells, GUS was the reporter gene of choice in these studies. GUS activity can be detected for several days after promoter activation (Weinmann et al., 1994). Three-wkold LapA1:GUS and WT plants were infested with $100 \mathrm{~B}$. tabaci. After $21 \mathrm{~d}$ of infestation, leaves had second, third, and early fourth-instar nymphs. As positive controls, leaves from developmentally matched plants were wounded by crushing or pin pricking. Both histochemical and fluorometric assays were performed.

Using the GUS histochemical detection method, no GUS activity was detected in controls or, more surprisingly, in wounded or JA-treated samples; however, GUS activities were readily detected using a GUS fluorometric assay (Table 1). The inability to detect GUS staining in older leaves in this study contrasted to previous reports that readily detected GUS histochemically after JA treatments in 7- to 10-day-old

Table 1 Fluorometric analysis of GUS activity in transgenic LapA1: $G U S$ tomato plants in response to wounding and whitefly feeding

\begin{tabular}{|c|c|c|}
\hline Treatment & $\begin{array}{l}\text { GUS activity }{ }^{\mathrm{a}} \\
\text { (pmol 4-MU/min/mg protein) }\end{array}$ & Average $^{b}$ \\
\hline \multirow[t]{2}{*}{ Untreated } & $\begin{array}{l}195.1 \pm 9.5 \\
342.6 \pm 8.5\end{array}$ & \multirow[t]{2}{*}{$248.9 \pm 81.42$} \\
\hline & $209.1 \pm 2.0$ & \\
\hline \multirow[t]{3}{*}{ B. tabaci } & $\begin{array}{l}430.8 \pm 26.4 \\
296.6 \pm 17.5\end{array}$ & \multirow[t]{3}{*}{$459.1 \pm 265.80$} \\
\hline & $843.1 \pm 13.3$ & \\
\hline & $266.0 \pm 31.8$ & \\
\hline \multirow[t]{5}{*}{ Crushing } & $\begin{aligned} 5585.5 & \pm 118.4 \\
10123.7 & \pm 774.5\end{aligned}$ & \multirow[t]{5}{*}{$6325.2 \pm 3328.47$ * } \\
\hline & $1850.0 \pm 38.4$ & \\
\hline & $3372.7 \pm 1460.4$ & \\
\hline & $9541.7 \pm 919.2$ & \\
\hline & $7477.3 \pm 360.2$ & \\
\hline \multirow[t]{3}{*}{ Pin pricks } & $\begin{array}{l}2416.6 \pm 215.3 \\
1334.7 \pm 38.8\end{array}$ & \multirow[t]{3}{*}{$1293.3 \pm 806.76$} \\
\hline & $638.2 \pm 6.3$ & \\
\hline & $783.5 \pm 101.9$ & \\
\hline
\end{tabular}

${ }^{\text {a }}$ GUS activity in leaf extracts from 6-week-old LapA1:GUS control plants (untreated) or LapA1:GUS plants infested with Bemisia tabaci biotype B $(20 \mathrm{~d})$, wounded by leaf lamina crushing $(24 \mathrm{hr})$, or wounded by pricking the leaf with a straight pin $(24 \mathrm{hr})$. GUS activities were measured in triplicate from individual plants and therefore reflect plant-to-plant variation in treatment responses. GUS and protein levels were determined as described in Methods and Materials. One representative experiment is displayed

${ }^{\mathrm{b}}$ Overall average for each treatment (+/- standard deviation). Bold numbers are statistically different from the "Untreated" sample determined by a $t$-test (2-tailed, unequal variance, 0.05 level). Numbers designated with an asterisk are significantly different from the " $B$. tabaci" treatment determined by a $t$-test (2-tailed, unequal variance, 0.05 level)
LapA1:GUS seedlings or in fruit or flowers (Chao et al., 1999). The reason GUS activity was difficult to detect in mature tomato leaves using the GUS histochemical method has not been identified. Variation of substrate infiltration regimes and pretreatments with hexane, DMSO or Silwet did not allow reproducible histochemical GUS detection in mature tomato leaves (see Methods and Materials).

For the reasons above, GUS activities in leaf extracts were monitored fluorometrically. These assays showed plant-to-plant variability in GUS activity levels in all treatments and controls; however, trends in GUS activities in the treated and control plants were readily discerned. Control, non-infested LapA1:GUS plants had low levels of GUS activity ranging from 195 to $342 \mathrm{pmol} 4-\mathrm{MU} / \mathrm{min} / \mathrm{mg}$ protein (Table 1) similar to that observed by Chao et al. (1999). Bemisia tabaci feeding caused no significant changes of GUS activity (Table 1). LapA1:GUS leaf lamina that were pin pricked to mimic mechanical damage (similar to that inflicted during feeding by some species of aphids) had higher levels of LapA promoter activity (2.6- to 9.7-fold); however, due to plant-to-plant variation, these values were not statistically significant from untreated leaves. Larger and statistically significant increases in LapA1 promoter activity (7 to 40-fold) were detected after the more severe mechanical wound (leaf crushing; Table 1), which is known to activate LapA1 (Chao et al., 1999).

PAL is Not a Good Molecular Sentinel for Whitefly Feeding Increases in $P A L$ transcripts have been correlated with wounding, pathogen infection and aphid feeding (Lee et al., 1994; Moran and Thompson, 2001). Therefore, the changes in PAL RNAs in response to B. tabaci and $T$. vaporariorum feeding were monitored from 0 to 9 days after infestation of tomato plants. Analysis of temporal and spatial RNA blot studies showed that PAL RNA levels increased transiently (days 1-5) and then declined (days 7-9) in both bagged (Control B) and unbagged (Control U) leaves and in apical leaves of control, non-infested plants (Fig. 1B). These data indicated that the small mechanical stresses that occurred during movement of the plants within the insect cages and not the process of encasing leaves in nylon bags were sufficient to increase $P A L$ transcript levels. In some experiments, large increases in $P A L$ transcripts were detected in infested leaves after 9 days of feeding by B. tabaci or $T$. vaporariorum relative to controls (Fig. 1A). In other experiments, PAL RNAs were only slightly elevated after $B$. tabaci feeding relative to controls on day 9 (Fig. 1B). While it appears that tomato $P A L$ genes respond to whitefly feeding, $P A L$ was not a reliable molecular marker for whitefly feeding responses.

Whiteflies Cause PR RNA Accumulation To determine if tomato $P R$ RNAs accumulated after whitefly feeding, the 
levels of GluB (basic $\beta$-1,3-glucanase), Chi9 (basic chitinase), $P R-1$ (P6 protein), PR-4 (P2 protein), GluAC (acidic $\beta$-1,3-glucanase), and Chi3 (acidic chitinase) transcripts were determined at 9 days after B. tabaci or T. vaporariorum infestation. Overall, similar gene expression patterns were noted after infestations with both species of whiteflies. GluB, Chi9, and PR-1 transcripts accumulated to high levels in infested leaves relative to the controls (Fig. 2A). Smaller increases in $P R-4$ and Chi3 RNAs were detected in infested leaves and GluAC transcripts were not detected (Fig. 2A).

The levels of $P R$ RNAs from infested and control plants were evaluated in infested and apical, non-infested leaves on days $0,1,3,5,7$, and 9 after $B$. tabaci and T. vaporariorum infestation. While six $P R$ gene RNAs were evaluated in this study (Table 2), only the GluB and PR-1 data are presented here (Fig. 2). GluB transcripts were first detected 5 days after infestation with $B$. tabaci and $T$. vaporariorum. GluB RNA levels peaked 7 days post infestation (Fig. 2B). GluB RNAs also were detected in the apical, non-infested leaves on day 7. $G l u B$ transcripts were not detected in the leaves from the two sets of control plants that had either had their leaves encased in insect-proof bags (Control B) or were not manipulated (Control U) (Fig. 2B).

The spatial and temporal patterns of $P R-1$ RNA accumulation were more complex. Over the 9-day infestation period, $P R-1$ RNA levels were modulated by developmental signals. This conclusion was based on the fact that PR-1 RNAs were detected at low levels in the non-infested leaves from both controls on days 1-3 and increased between days 5 and 7 (Fig. 2C). In addition, low levels of $P R-1$ RNAs were detected in apical leaves on days 5-9, reflecting the younger age of these leaves and the beginning of the PR-1 developmental program (Fig. 2C). It should be noted that these leaves showed no signs of senescence, and therefore $P R-1$ transcript levels could not be attributed to initiation of the senescence program, as has been previously reported (John et al., 1997). Despite this developmental regulation, it was clear that both $B$. tabaci and $T$. vaporariorum feeding enhanced $P R-1$ transcript accumulation in infested leaves relative to control plants. Differences in $P R$ 1 transcript levels in apical leaves from infested or noninfested plants also were observed in this experiment (Fig. 2C). In other replicate experiments, the systemic accumulation of $P R-1$ RNAs was not as pronounced (Fig. 2A; data not shown).

Changes in Chi3, Chi9, GluAC, and PAL-Transcripts in Response to Wound and Defense Signals The responses of the tomato $P R$ genes encoding the GluB, PR-4, and $P R-1$ to wound and defense signals (i.e., MeJA, systemin, ABA, ethylene, and SA) in the tomato cultivar UC82b were reported previously (Chao et al., 1999) and are summarized in Table 2. To understand the potential defense signals important in the regulation of other tomato defense genes used in this study, the accumulation of transcripts for Chi3, GluAC, Chi9, and PAL5 was determined after SA, MeJA, systemin, ABA, and ethylene treatments (Fig. 3; Table 2). Like previously characterized $P R$ genes (Chao et al., 1999), GluAC, Chi9, and Chi3 RNAs did not accumulate in response to systemin or ABA treatments.

Both Chi9 and GluB encode proteins with a vacuolar location (van Kan et al., 1995). Chi9 transcripts accumulated with a pattern similar to GluB RNAs; Chi9 and GluB RNAs were most abundant after MeJA and ethylene treatments (Fig. 3; Chao et al., 1999). The dependence of GluB, Chi9, and PR-1 RNA accumulation on ethylene signal transduction also has been supported by the analysis of mutant tomatoes expressing the $\mathrm{Nr}$ mutation, overexpressing the wild type NR, or down-regulating tomato ETR genes (Ciardi et al., 2001). Chi9 RNA levels also were elevated in control treatments, as previously reported for GluB and PR-1 (Chao et al., 1999). This may be due to a volatile released by control plants that accumulates in the enclosed environments used for the ethylene and MeJA treatments. Notably, LapA, Chi3 and GluAC were not modulated by this additional defense signal.

Chi3 and GluAC encode apoplastic proteins (van Kan et al., 1995). Similar to the pattern previously reported for PR4 (Chao et al., 1999), Chi3 and GluAC transcripts were most abundant after ethylene treatments (Fig. 3). Of the three $P R$ genes examined in this study, only Chi3 transcripts accumulated in response to exogenous SA. These data contrast to studies by van Kan et al. (1995) who showed increases in Chi3 and GluAC RNAs after treatment with $1 \mathrm{mM} \mathrm{SA}$. This may be due to the facts that van Kan et al. (1995) used a different tomato cultivar, applied SA to petioles (vs. seedling shoots in this paper), and/or used a higher concentration of SA (1 mM). In the excised seedling assay used here, $1 \mathrm{mM} \mathrm{SA}$ caused necrosis in the UC $82 \mathrm{~b}$ cultivar and could not be evaluated (Chao et al., 1999).

Surprisingly little is known about PAL5 expression after biotic stress in tomato plants (Gorlach et al., 1995). Figure 3 shows that tomato PAL5 transcripts were detected in all control and treated leaf samples. PAL5 RNAs increased in response to MeJA (3-fold) and smaller increases (1.4- to 2.0-fold) were seen with ethylene and ABA treatments (Fig. 3). In contrast, PAL5 RNA levels declined after treatments with $0.1,0.2$ and $0.5 \mathrm{mM} \mathrm{SA}$ relative to control.

\section{Discussion}

The ability of plants to quickly and accurately perceive their biotic attackers is essential for mounting an effective defense. Plants must identify and respond to the chemical 
A

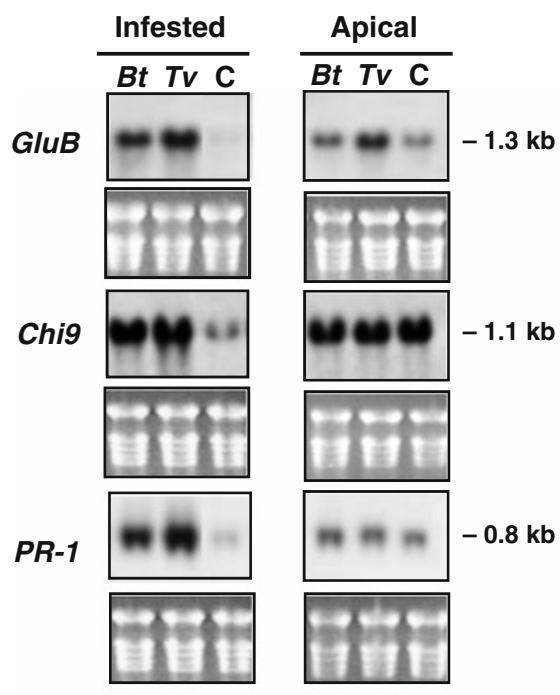

B

GluB

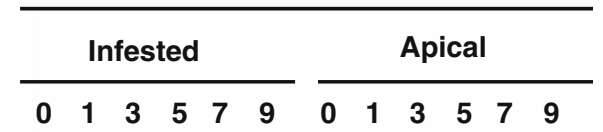

B. tabaci
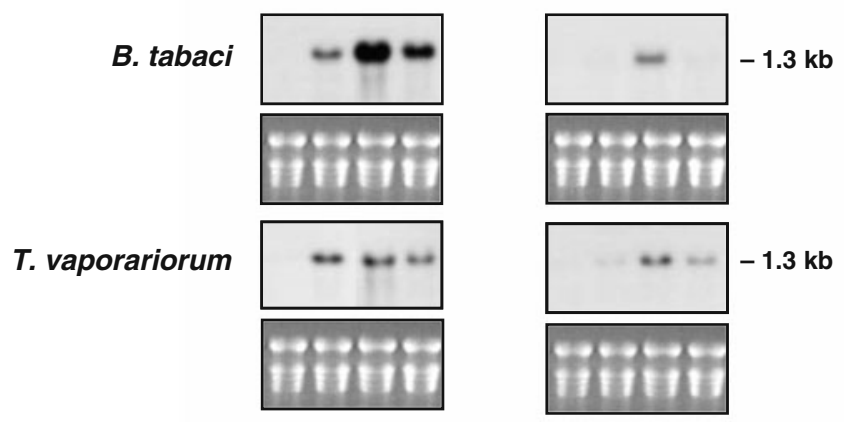

Control B
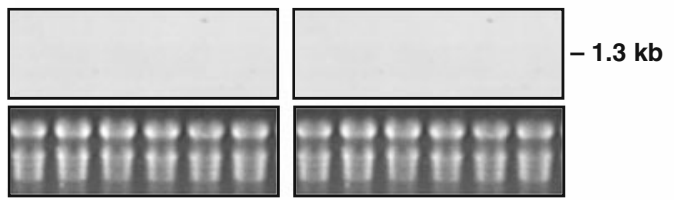

Control U
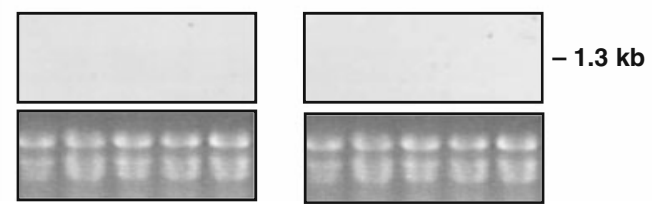

Fig. 2 Changes in $P R$ gene RNA levels in response to whitefly feeding. A Tomato plants were infested with Besimia tabaci biotype B $(B t)$ or Trialeurodes vaporariorum $(T v)$ or served as non-infested controls (C). Control leaves were encased and nylon bags but insects were not added as described in Fig. 1A. Total RNA blots were hybridized with ${ }^{32} \mathrm{P}$-labeled basic $\beta$-1,3-glucanase $(G l u B)$, basic chitinase (Chi9), PR-1 (P6), PR-4, acidic chitinase (Chi3), or acidic $\beta$-1,3-glucanase (GluAC) cDNA probes. Experiments were repeated once and each lane is pooled leaf material from three plants. Film exposure times were: $3 \mathrm{~d}$ for Chi9, GluB, and PR-4; $2 \mathrm{~d}$ for $P R-1$,
C

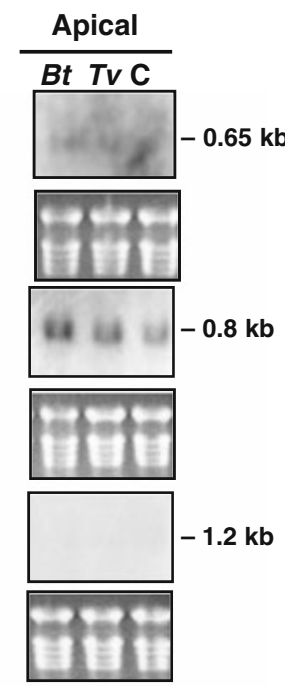

PR-1

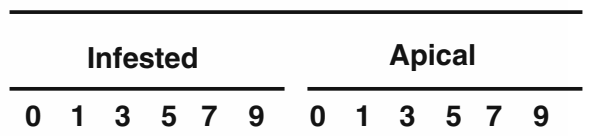

B. tabaci
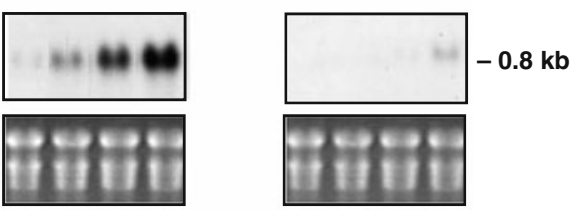

T. vaporariorum
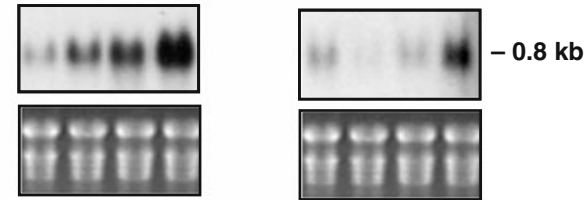

Control B
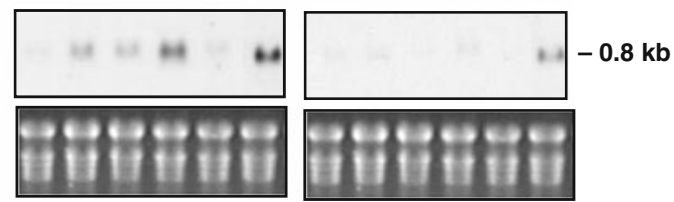

Control U
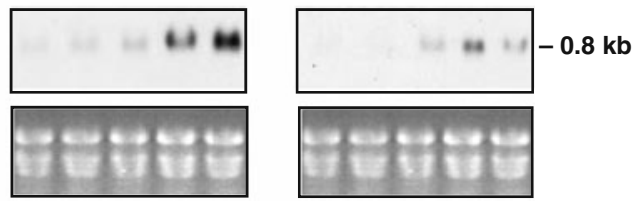

4 days for Chi3; $6 \mathrm{~d}$ for GluA, B, C Plants were infested as in Fig. 1B. Infested and apical, non-infested leaves were harvested $0,3,5,7$, and $9 \mathrm{~d}$ after B. tabaci biotype B (Bt) or T. vaporariorum (Tv) infestation. Controls were leaves from bagged but non-infested (Control B) or untreated (Control $\mathrm{U}$ ) plants. RNA blots were hybridized to each ${ }^{32} \mathrm{P}$ labeled $P R$ gene probe in Panel A; only data from the GluB (Panel B) or PR-1 (Panel C) probes are shown in Panel B. Stained gels visualizing rRNAs are shown as a loading control. Film exposures time were $2 \mathrm{~d}$ 
Table 2 Tomato wound- and defense-response gene expression

\begin{tabular}{|c|c|c|c|c|c|c|c|}
\hline \multirow[t]{2}{*}{ Gene } & \multirow[t]{2}{*}{ Protein } & \multicolumn{6}{|c|}{ Relative RNA increases in response to wound and defense signals ${ }^{\mathrm{a}}$} \\
\hline & & WF & MeJA & Eth & $\mathrm{ABA}$ & SYS & $\mathrm{SA}$ \\
\hline $\operatorname{Lap} A^{\mathrm{b}}$ & Leucine aminopeptidase & o & +++ & + & + & +++ & - \\
\hline $\operatorname{pin} 2^{\mathrm{c}}$ & Proteinase inhibitor II & o & +++ & - & + & +++ & - \\
\hline$P A L^{\mathrm{d}}$ & Phenylalanine ammonia lyase & $+/++$ & + & + & + & o & - \\
\hline$G l u B^{\mathrm{b}}$ & Basic $\beta$-1,3-glucanase & ++ & $+^{\mathrm{e}}$ & $++^{e}$ & o & - & + \\
\hline$C h i 9^{\mathrm{d}}$ & Basic chitinase & ++ & $++^{\mathrm{e}}$ & $+^{\mathrm{e}}$ & o & o & o \\
\hline$P R-1^{\mathrm{b}}$ & P6 protein (PR-1-like protein) & ++ & $++^{\mathrm{e}}$ & $+++^{\mathrm{e}}$ & o & o & +++ \\
\hline$G l u A C^{\mathrm{d}}$ & Acidic $\beta$-1,3-glucanase & o & + & +++ & o & - & o \\
\hline$C h i 3^{\mathrm{d}}$ & Acidic chitinase & + & + & +++ & - & o & ++ \\
\hline$P R-4^{\mathrm{b}}$ & P2 protein (win-like protein) & + & o & +++ & o & o & o \\
\hline
\end{tabular}

${ }^{a}$ Fold increase in RNAs relative to control samples was determined by phosphoimager quantitation of RNA blot signals. RNAs that were unchanged or declined relative to control are indicated with a zero (o) or minus symbol (-), respectively. RNAs that increased are indicated with plus symbols: from 1.5 to 3.0 fold $(+), 3.1$ to 10 fold $(++)$, and greater than 10 fold $(+++)$. Treatments included silverleaf or greenhouse whitefly infestations (WF), $100 \mu \mathrm{M}$ methyl jasmonate (MeJA), 29 ppm ethylene (Eth), $100 \mu \mathrm{M}$ abscisic acid (ABA), 1 pmol systemin (Sys), and $0.25 \mathrm{mM}$ salicylic acid (SA)

${ }^{\mathrm{b}}$ Defense chemical treatment data are from Chao et al. (1999). Whitefly-response data appear in this paper

${ }^{\mathrm{c}}$ The pin 2 probe was hybridized to a RNA blot similar to that shown in Fig. 3 and autoradiographic signals quantitated (data not shown). Whitefly response data appear in this paper

${ }^{\mathrm{d}}$ Defense chemical treatment and whitefly-response data appear in this paper

${ }^{\mathrm{e}}$ Control samples had elevated levels of these transcripts relative to other genes, therefore increases in these RNA levels may be underestimated. Discussion of these results are in Chao et al. (1999)

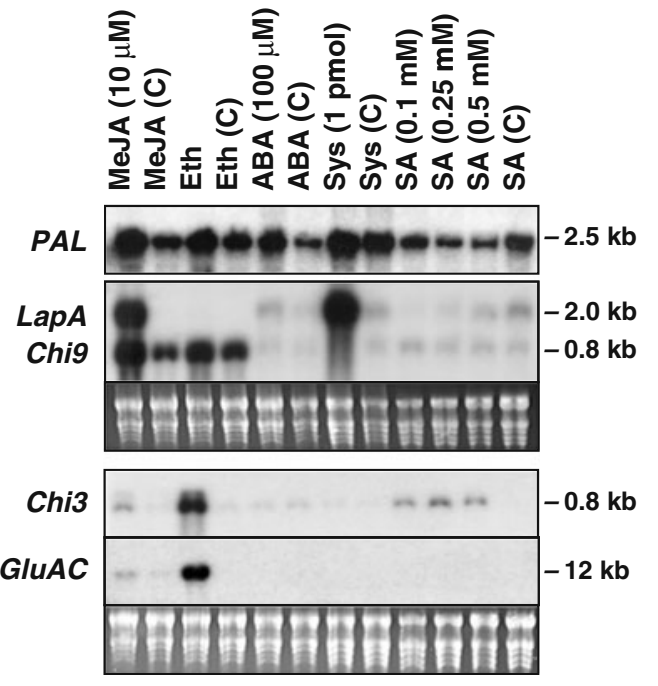

Fig. 3 RNA blot analyses of wound- and defense-response RNAs in tomato plants treated with defense signals. Excised tomato seedlings were treated with $10 \mu \mathrm{M}$ MeJA, $29 \mathrm{ppm}$ ethylene (Eth), $100 \mu \mathrm{M}$ ABA, 1.0 pmol systemin (Sys), or $0.1,0.25$, or $0.5 \mathrm{mM}$ SA. For each treatment, the corresponding control is shown (C). Total RNA blots were hybridized to ${ }^{32} \mathrm{P}$-labeled PAL, LapA, Chi9, Chi3, and GluAC probes. Transcript sizes are shown in $\mathrm{kb}$ and were determined using a RNA marker run in a parallel lane. Stained gels visualizing rRNAs are shown as a loading control. The stained gel for the PAL5 blot is not shown. Exposure times were 21-23 hr (effectors) and mechanical signals that accompany pest attack (Felton and Tumlinson, 2008; Howe and Jander, 2008; Walling, 2009; Wu and Baldwin, 2009). Previous studies have indicated that plants can discriminate signals introduced by closely related arthropods, such as whitefly, aphid and spider mite biotypes (van de Ven et al., 2000; Hebert et al., 2007; Kant et al., 2008). For example, squash plants can perceive differences in the signals delivered by B. tabaci biotypes A and B. Only biotype B causes the squash leaf silvering disorder and preferentially induces the defense-response genes $S L W 1$ and $S L W 3$ (van de Ven et al., 2000). It is presumed that the B. tabaci biotype B effectors, which elicit these biotype-specific changes in gene expression and leaf development programs, are of insect or endosymbiont origin and introduced via the rapidly gelling or watery salivas of the whitefly (van de Ven et al., 2000).

For the reasons above, it was of interest to understand if two distinct whitefly species-B. tabaci and $T$. vaporariorum - would provoke similar or distinct defense gene expression programs in tomato. While B. tabaci and $T$. vaporariorum both have broad host ranges and use similar mechanical strategies to recover nutrients from the phloem, their ability to vector viruses and cause developmental disorders are distinct (Inbar and Gerling, 2008). Bemisia tabaci biotype B, but not $T$. vaporariorum, causes the tomato irregular fruit-ripening disorder (Schuster et al., 1990), but neither of these whiteflies induces leaf silvering in tomato. The data presented here showed that $B$. tabaci 
and T. vaporariorum feeding on tomato leaves induce similar temporal and spatial patterns of defense- and wound-response gene expression. These results indicate that these whiteflies must introduce effectors with similar chemical structure(s) or activities to regulate wound- and defense-response gene expression. Furthermore, these whiteflies must also introduce species-specific effectors to cause the irregular-ripening disorder.

This study used nine tomato wound- and defenseresponse genes to assess defense responses to $B$. tabaci and $T$. vaporariorum. These genes included two wellcharacterized wound-response genes (Pin2 and LapA) that are known to be JA-responsive and dependent on the jasmonate receptor JAI1 (COI1) (Chao et al., 1999; Li et al., 2004). PAL5, which encodes a rate-limiting enzyme for the shikimate pathway that provides the chemical precursors for phenolic compounds used for cell wall strengthening and as anti-nutritive compounds, also has been studied (Dixon et al., 2002). PAL5 RNAs accumulate in response to a wide variety of biotic stresses; however, little was known about tomato PAL5 responses to defense signals (Chang et al., 2008; Guo and Wang, 2009). The studies presented here show that tomato PAL5 RNAs decreased in response to SA and increase after MeJA, ethylene, and ABA treatments (Table 2). PAL5 RNA accumulation patterns reported here are consistent with the results of Lee et al. (1994). These investigators reported two PAL5 RNA forms; the long PAL5 RNA is detected constitutively, while the short PAL5 RNA accumulates in response to wounding and pathogen infection.

The third group of tomato genes studied included six $P R$ genes (GluB, Chi9, PR-1, GluAC, Chi3, and PR-4) that respond to pathogen attack (van Kan et al., 1995). Treatments of excised seedlings with MeJA, ABA, SA, systemin, and ethylene indicate that these genes display four basic expression programs (Table 2; Chao et al., 1999). All $P R$ genes were ethylene responsive, and their response to exogenous MeJA and/or SA distinguished the $P R$ genes further. GluB, Chi9, and PR-1 (P6) transcripts increased in response to exogenous MeJA. However, their regulation was distinctive from Pin2 and LapA, since GluB, Chi9, and $P R-1$ RNAs did not increase in response to exogenous ABA or systemin (Table 2; Chao et al., 1999). Unlike GluB and Chi9, $P R-1$ RNAs increased after SA treatments (Table 2). In contrast, Chi3 and $P R-4$ transcripts accumulated to low levels and GluAC RNAs were barely detected in response to exogenous MeJA; only Chi3 RNA levels were modulated by SA (Table 2; Chao et al., 1999).

One prevailing theme from the studies presented here is that the tomato response to phloem-feeding whiteflies has a compelling similarity to pathogen infection (van Loon et al., 2006). $P R$ RNAs and proteins accumulate after infection with both biotrophic and necotrophic pathogens in tomato including avirulent and virulent Cladosporium fulvum (Cooke.) (van Kan et al., 1992), Fusarium oxysporum (Schlecht) (Rep et al., 2002), Phytophthora infestans (Mont. de Bary) (Christ and Mosinger, 1989), and Botrytis cinerea (Pers.) (Benito et al., 1998). Both B. tabaci and T. vaporariorum infestations resulted in similar patterns of $P R$ gene expression. $P R$ RNAs were not detected at 1 or 3 days after whitefly infestation, indicating that a total of 500 adult whiteflies per plant $(250$ adults/leaf $\times 2$ leaves) were insufficient to cause $P R$ RNAs to accumulate locally or systemically. Five days after infestation, GluB, Chi9, and PR-1 transcripts became abundant in the whitefly-infested leaves, and GluB RNAs accumulated systemically by day 7. Chi3 and $P R-4$ RNAs also increased but were less abundant and GluAC RNAs were barely detected after whitefly feeding.

The increases in PR RNAs correlated with the time of crawler emergence from eggs and the initiation of nymph feeding. Therefore, it is not clear if adults lacked the salivary effectors to activate $P R$ gene expression, or if the changes in $P R$ gene expression were dependent on the larger number of insects feeding during days 5-9. It is noteworthy, that B. tabaci biotype B leaf silvering of squash plants was thought initially to be a nymph-specific disorder, since as few as three feeding nymphs can cause squash leaf silvering (Costa et al., 1993). Recently, it was shown that large numbers of male B. tabaci biotype B infest squash are capable of inducing leaf silvering (De Barro and Khan, 2007). These data suggest that large numbers of adult whiteflies may be needed for tomato or squash plants to perceive whitefly effectors to induce defense genes and developmental disorders, respectively. This may reflect differences in the potency or quantities of effectors in adult whitefly saliva or the amount of time adults spend salivating relative to nymphs.

When the responsiveness of different $P R$ genes to whitefly feeding and exogenous hormone treatments were examined collectively, the role of the defense-signaling pathways in the tomato-whitefly interactions could be proposed (Table 2, Fig. 3, Chao et al., 1999). This was based on the presumption that exogenous hormone treatments accurately report the roles of defense hormone signaling pathways after whitefly infestation. It is clear that all six $P R$ genes examined in this study were complexly regulated, since these $P R$ genes responded to two or more defense-hormones (i.e., MeJA, ethylene, and/or SA). As developed below, it is clear that no one defense hormone can explain $P R$ gene regulation after whitefly infestation. Therefore, it is likely that multiple hormones act together to orchestrate this defense response; the possibility of a novel signal transduction pathway involvement cannot be excluded at this time.

It appears unlikely that a rise in ethylene can explain the induction of $P R$ genes after whitefly feeding. This 
conclusion is based on the facts that all six $P R$ RNAs accumulated in response to exogenous ethylene, but GluAC RNAs did not accumulate after whitefly feeding. Increases in ethylene and induction of ethylene pathway genes have been noted during aphid infestations of both susceptible and resistant tomato, barley and melon plants (Argañdona et al., 2001; Mantelin et al., 2009; Anstead et al., 2010). In the M. eurphorbiae-tomato interaction, the ability to perceive ethylene is important for basal resistance (innate immunity) but not gene-for-gene resistance (Mantelin et al., 2009).

$P R$ RNA levels after whitefly feeding were not correlated with responsiveness to $\mathrm{SA}$, for only three of the five $P R$ RNAs that accumulated were SA-regulated. This is a fundamental difference in the regulation of $P R$ genes in tomato vs. Arabidopsis. Most $P R$ genes in Arabidopsis are SA-regulated and suppressed by whitefly feeding (van Loon et al., 2006; Zarate et al., 2007).

Finally, the $P R$ RNAs that were most abundant after whitefly feeding also increased markedly after MeJA treatments. This suggests that the JA-pathway may be activated after whitefly feeding. However, it should be noted that there was not a strict correlation of MeJA and whitefly responsiveness, since GluAC RNAs accumulated in response to MeJA treatments but not after whitefly infestation, and $P R-4$ was whitefly induced but did not respond to exogenous MeJA. Several other genes induced by whitefly infestation are known to be regulated by MeJA. This includes a whitefly-induced tomato gene (Wfil) that encodes a subunit of the NADPH oxidase (D.P. Puthoff and L.L. Walling, unpublished results) and the squash SLW1 gene that is preferentially induced by the $B$. tabaci biotype B (van de Ven et al., 2000). These observations in tomato are in marked contrast to the changes in gene expression observed after the B. tabaci interactions in Arabidopsis, where SA-regulated $P R$ RNAs accumulate and JAregulated wound/defense response genes are suppressed (Kempema et al., 2007; Zarate et al., 2007). In addition, $B$. tabaci infestations of Lima bean (Zhang et al., 2009) and Arabidopsis (Zarate, Navarre and Walling, unpublished results) cause increases in SA levels; the changes in SA and JA levels after whitefly infestation of tomatoes has not yet been assessed.

While JA-regulated $P R$ RNAs are abundant after whitefly feeding, this was not the case for JA-regulated wound-response genes. Two sets of data indicate that heavy infestations (up to 10 insects per $\mathrm{cm}^{2}$ ) by $B$. tabaci and $T$. vaporariorum did not activate the wound-signaling pathway in tomato. First, feeding by over $500 \mathrm{~B}$. tabaci adults (day 3) and over 2,000 B. tabaci nymphs and 500 adults (day 5) per tomato leaf were not sufficient to increase LapA or pin2 transcripts to detectable levels locally or systemically. Second, B. tabaci infestation of transgenic LapA1:GUS tomato plants showed that the LapAl promoter activity was similar in leaves of B. tabaci-infested and non-infested control plants. These data suggest that the whitefly stylet's piercing of epidermal cells, movement between cells (which disrupts essential cell-to-cell contacts), puncturing of the sieve elements, and consumption of phloem nutrients were not perceived as sufficient physical or mechanical stresses to activate the tomato JA-dependent wound-response pathway (Walling, 2008).

These data also indicate that tomato responses to whitefly adult and nymph feeding were distinct from responses to tissue-damaging herbivores. Caterpillars, beetles, and cell-content feeding spider mites and thrips all induce JA-regulated wound-response gene expression in tomato (Pautot et al., 1993; Li et al., 2002; Ament et al., 2004). This regulation occurs at the transcriptional level, since Pin 2 and LapA promoter:reporter genes are activated by wounding and caterpillar feeding in transgenic tomato, potato, tobacco, silver birch, Arabidopsis, and white spruce (Thornburg et al., 1990; Keinonen-Mettälä et al., 1998; Chao et al., 1999; Godard et al., 2007).

Pin2 genes also are induced in some, but not all, aphidplant interactions (Thornburg et al., 1990; Fidantsef et al., 1999; de Ilarduya et al., 2003). Consistent with aphids piercing mesophyll cells in their search for a phloem-sieve element, the potato aphid (M. euphorbiae) and green peach aphid [Myzus persicae (Sulzer)] infestations of tomato plants cause Pin1 and Pin2 RNA levels to increase transiently (6-12 hr post infestation), and prior to the accumulation of $P R$ RNAs (12-48 hr post infestation) (de Ilarduya et al., 2003). Consistent with this result, Pin2 RNAs were not detectable 7 days after $M$. euphorbiae feeding (Fidantsef et al., 1999). Interestingly, the Pin2 promoter was not activated after a non-synchronous aphid infestation of transgenic Pin2:CAT tobacco plants in the field (Thornburg et al., 1990).

Whiteflies may avoid activation of wound-responses due to their refined feeding behaviors that avoid puncturing mesophyll cells, which distinguishes feeding by whiteflies from aphids (Tjallingii, 2006; Walling, 2008). It is also possible that chemical constituents of the watery and gelling salivas of whitefly adults and nymphs do not activate the JA-dependent wound signaling pathway. Alternatively, whitefly salivary factors may directly or indirectly antagonize the tomato wound-response pathway. Since whiteflies are known to increase SA levels during infestation of Arabidopsis and Lima beans (Zhang et al., 2009; Zarate, Navarre, and Walling, unpublished results), it is possible that the increases in SA promote the antagonistic cross-talk between the JA- and SA-defenses. Cross-talk, which is known to occur in the B. tabaci-Arabidopsis and in other biotic interactions, may suppress the JA-regulated traits that slow nymph development (Thaler et al., 2002; 
Zarate et al., 2007; Koornneef et al., 2008). In addition, there is substantial evidence for constituents of hemipteran saliva influencing insect-plant interactions (Miles, 1999; Felton and Tumlinson, 2008; Walling, 2009). Some aphid salivary proteins appear important in chelating calcium to influence wound-induced protein coagulation at stylet punctures of the phloem (Will et al., 2007). Saliva constituents also contribute to aphid fitness, activate/ suppress plant gene expression, induce a local resistance to further aphid infestations, and induce infestation symptoms (Lapitan et al., 2007; Mutti et al., 2008; De Vos and Jander, 2009). Some caterpillars and beetles have oral or salivary secretions that antagonize activation of woundresponse genes. These interactions include: the corn earworm [Helicoverpa zea (Boddie)] with tobacco [(Nicotiana tabacum (L.)], the beet armyworm [Spodoptera exigua (Hübner)] with Medicago truncatula (Gaertn), the Colorado potato beetle [Leptinotarsa decemlineata (Say)] with tomato, and the small white butterfly larvae [Pieris rapae (L.)] with Arabidopsis (Reymond et al., 2000; Musser et al., 2002; Bede et al., 2006; Lawrence et al., 2007).

Avoiding activation of wound-responses may contribute to the success of $B$. tabaci and T. vaporariorum on their hosts (Walling, 2008), and this appears to be the case for $B$. tabaci interactions in Arabidopsis (Kempema et al., 2007; Zarate et al., 2007). However, in tomato, the role of JAregulated defense traits against whiteflies is not as well understood. Sánchez-Hernández et al. (2006) showed that the tomato spr2 (suppressor of prosystemin-mediated responses2) mutant and transgenic line that ectopically expresses Prosystemin (35S:ProSys) influences whiteflytomato interactions. The $s p r 2$ mutant blocks JA biosynthesis and alters volatile emission profiles (Sánchez-Hernández et al., 2006). The 35S:ProSys line over-expresses the wound peptide precursor Prosystemin and has constitutively activated wound-response genes (McGurl et al., 1994). Bemisia tabaci adults prefer to oviposit on spr 2 plants, indicating that $\mathrm{JA}$ is essential for the production of volatiles that deter $B$. tabaci acceptance of tomato plants; however, 35S:Prosys plants did not display the expected reciprocal phenotype (i.e., repellency) (Sánchez-Hernández et al., 2006). When adult eclosion from fourth-instar nymphs was monitored, fewer adults emerged from 35S:Prosys plants than wild-type or spr 2 plants (Sánchez-Hernández et al., 2006). These data suggest that ectopic expression of the tomato woundresponse pathway may impede $B$. tabaci development at the level(s) of nymph settling or development. Therefore, avoiding activation of the wound-response pathway of tomato would be advantageous to whitefly success, as it is in the model plant Arabidopsis (Zarate et al., 2007).

The importance of $P R$ gene products in defense against phloem-feeding insects is not understood at the present time. In tomato, the $P R$ genes that responded most strongly to whitefly feeding encoded proteins with either a vacuolar (Chi9 and GluB) or an apoplastic (PR-1) location (van Kan et al., 1995). Aphid feeding also causes $G l u B$ and $P R-1$ RNAs to increase in tomato (de Ilarduya et al., 2003). Unlike aphids, it is anticipated that whiteflies would have limited contact with the vacuolar $P R$ proteins, since their mouthparts rarely pierce mesophyll cells during the search for a feeding site in the phloem. It seems likely that whiteflies would contact the apoplastic proteins, such as $P R-1$ protein. The exterior of whitefly mouthparts would have limited physical contact with $P R-1$ due to the salivary sheath that encases the flexible whitefly stylet. In contrast, whiteflies may consume minute quantities of apoplastic proteins and chemicals, as they secrete and then ingest, a watery saliva to "taste" the chemical environment of the apoplast (Lei et al., 1998a). It is thought that whiteflies use these gustatory cues as indicators of hostplant suitability and as signals to guide the stylet's route to the phloem sieve element. Consistent with this is the fact that the tomato resistance gene $M i-1$, which mediates a modest resistance to whiteflies, appears to influence resistance traits that act prior to phloem feeding (Jiang et al., 2001).

Since whiteflies recover their nutrients from the phloem and occasionally drink water from xylem (Lei et al., 1998b), the phloem and xylem are additional sites for proteins/chemicals that can influence whitefly-plant interactions. For example, some aphid-resistance $(R)$ genes control a phloem-localized resistance traits (Kaloshian et al., 1995; Klingler et al., 1998). It is not clear whether the tomato $P R$ proteins accumulate in the phloem or xylem after hemipteran feeding, although some $P R$ proteins have been reported in xylem sap of Fusarium oxysporum-infected tomato plants (Rep et al., 2002). Furthermore, the transcriptome of phloem sap, phloem tissue and vascular-enriched tissue have shown that some stress-related RNAs, including some $P R$ RNAs, are detected in the phloem (Le Hir et al., 2008). The role of phloem- or xylem-localized PRs or other phloem-localized proteins that deter aphids (Yoo et al., 2000), on whitefly host acceptance, longevity, fecundity, and nymph development has yet to be tested.

Acknowledgements This research was partially supported by a UC biotechnology grant, a USDA grant (99-35301-8077) and NSF grant (IOS-0725093). D.P.P. was supported by the National Science Foundation training grant (GER-5355042). We thank Walling laboratory members, especially C.S. LeVesque and W.T.G van de Ven for helpful discussions and W.S. Chao for use of RNAs.

Open Access This article is distributed under the terms of the Creative Commons Attribution Noncommercial License which permits any noncommercial use, distribution, and reproduction in any medium, provided the original author(s) and source are credited. 


\section{References}

Ament, K., Kant, M. R., Sabelis, M. W., Haring, M. A., and SCHUURINK, R. C. 2004. Jasmonic acid is a key regulator of spider mite-induced volatile terpenoid and methyl salicylate emission in tomato. Plant Physiol. 135:2025-2037.

Anstead, J., Samuel, P., Song, N., Wu, C. J., Thompson, G. A., and GoggIN, F. 2010. Activation of ethylene-related genes in response to aphid feeding on resistant and susceptible melon and tomato plants. Entomol. Exp. Appl. 134:170-181.

Antony, B., and Palaniswami, M. S. 2006. Bemisia tabaci feeding induces pathogenesis related proteins in cassava (Manihot esculenta Crantz). Indian J. Biochem. Biophys. 43:182-185.

Argañdona, V. H., Chaman, M., CARdemil, L., Muñoz, O., ZÚNIIGA, G. E., and CORCUERA, L. J. 2001. Ethylene production and peroxidase activity in aphid-infested barley. J. Chem. Ecol. 27:53-68.

Bede, J. C., Musser, R. O., Felton, G. W., and Korth, K. L. 2006. Caterpillar herbivory and salivary enzymes decrease transcript levels of Medicago truncatula genes encoding early enzymes in terpenoid biosynthesis. Plant Mol. Biol. 60:519-531.

Benito, E. P., ArJen ten, H., Klooster, J. W. V., and van Kan, J. A. L. 1998. Fungal and plant gene expression during synchronized infection of tomato leaves by Botrytis cinerea. Eur. J. Plant Pathol. 104:207-220.

Bhattarai, K. K., Hagop, S. A., Kaloshian, I., and Eulgem, T. 2010. WRKY72-type transcription factors contribute to basal immunity in tomato and Arabidopsis as well as gene-for-gene resistance mediated by the tomato $R$ gene Mi-l Plant $J$. Published Online: 19 Apr 2010.

Birkett, M. A., Chamberlain, K., Guerrieri, E., Pickett, J. A., WADHAMS, L. J., and YASUDA, T. 2003. Volatiles from whiteflyinfested plants elicit a host-locating response in the parasitoid, Encarsia formosa. J. Chem. Ecol. 29:1589-1600.

Chang, A., Lim, M. H., Lee, S. W., RobB, E. J., and NAZAR, R. N. 2008. Tomato phenylalanine ammonia lyase gene family, highly redundant but strongly underutilized. J. Biol. Chem. 283:3359133601 .

Chao, W. S., Gu, Y.-Q., Pautot, V., Bray, E. A., and Walling, L. L. 1999. Leucine aminopeptidase mRNAs, proteins and activities increase in response to drought, salinity and the wound signalssystemin, methyl jasmonate, and abscisic acid. Plant Physiol. 120:979-992.

Christ, U., and Mosinger, E. 1989. Pathogenesis-related proteins of tomato: I. Induction by Phytophthora infestans and other biotic and abiotic inducers and correlations with resistance. Physiol. Mol. Plant Pathol. 35:53-66.

Ciardi, J. A., Tieman, D. M., Jones, J. B., and KleE, H. J. 2001. Reduced expression of the tomato ethylene receptor gene LeETR4 enhances the hypersensitive response to Xanthomonas campestris pv. vesicatoria. Mol. Plant-Microb. Interact. 14:487-495.

Costa, H. S., Ulmanh, D. E., Johnson, M. W., and Tabashnik, B. E. 1993. Squash silverleaf symptoms induced by immature but not adult Bemisia tabaci. Phytopathology 83:763-766.

De BARro, P., and KhAN, S. 2007. Adult Bemisia tabaci biotype B can induce silverleafing in squash. Bull. Entomol. Res. 97:433436.

De Barro, P. J., Trueman, J. W. H., and Frohlich, D. R. 2005. Bemisia argentifolii is a race of $B$. tabaci (Hemiptera : Aleyrodidae): the molecular genetic differentiation of $B$. tabaci populations around the world. Bull. Entomol. Res. 95:193-203.

De Ilarduya, O. M., XIE, Q. G., and Kaloshian, I. 2003. Aphidinduced defense responses in Mi-1-mediated compatible and incompatible tomato interactions. Mol. Plant-Microb. Interact. 16:699-708.
DE Vos, M., and JANDER, G. 2009. Myzus persicae (green peach aphid) salivary components induce defence responses in Arabidopsis thaliana. Plant Cell Environ. 32:1548-1560.

De Vos, M., van Zaanen, W., Koornneef, A., Korzelius, J. P., Dicke, M., VAN LoON, L. C., and Pieterse, C. M. J. 2006. Herbivore-induced resistance against microbial pathogens in Arabidopsis. Plant Physiol. 142:352-363.

Delatte, H., Reynaud, B., Granier, M., Thornary, L., Lett, J. M., Goldbach, R., and Peterschmitt, M. 2005. A new silverleaf-inducing biotype Ms of Bemisia tabaci (Hemiptera: Aleyrodidae) indigenous to the islands of the south-west Indian Ocean. Bull. Entomol. Res. 95:29-35.

DickE, M., and BALDWIN, I. T. 2010. The evolutionary context for herbivore-induced plant volatiles: beyond the 'cry for help'. Trends Plant Sci. 15:167-175.

Dixon, R. A., Achnine, L., KotA, P., Liu, C. J., RedDy, M. S. S., and WANG, L. J. 2002. The phenylpropanoid pathway and plant defence - a genomics perspective. Mol. Plant Pathol. 3:371-390.

Estrada-HernandeZ, M. G., VAlEnZUEla-Soto, J. H., IBARRALaClette, E., and Delano-Frier, J. P. 2009. Differential gene expression in whitefly Bemisia tabaci-infested tomato (Solanum lycopersicum) plants at progressing developmental stages of the insect's life cycle. Physiol. Plant. 137:44-60.

Fatouros, N. E., Pashalidou, F. G., Corder, W. V. A., VAn LoOn, J. J. A., Mumm, R., Dicke, M., Hilker, M., and Huigens, M. E. 2009. Anti-aphrodisiac compounds of male butterflies increase the risk of egg parasitoid attack by inducing plant synonome production. J. Chem. Ecol. 35:1373-1381

FELtON, G. W., and TUMLINSON, J. H. 2008. Plant-insect dialogs: complex interactions at the plant-insect interface. Curr. Opin. Plant Biol. 11:457-463.

Fidantsef, A. L., Stout, M. J., Thaler, J. S., Duffey, S. S., and Bostock, R. M. 1999. Signal interactions in pathogen and insect attack: expression of lipoxygenase, proteinase inhibitor II, and pathogenesis-related protein $\mathrm{P} 4$ in the tomato, Lycopersicon esculentum. Physiol. Mol. Plant Pathol. 54:97-114.

GLAZEBROOK, J. 2005. Contrasting mechanisms of defense against biotrophic and necrotrophic pathogens. Annu. Rev. Phytopathol. 43:205-227.

Godard, K. A., Byun-McKay, A., Levasseur, C., Plant, A., Seguin, A., and BohlmanN, J. 2007. Testing of a heterologous, wound- and insect-inducible promoter for functional genomics studies in conifer defense. Plant Cell Rep. 26:2083-2090.

Gorlach, J., RAESECKE, H.-R., RENTSCH, D., REgenass, M., Roy, P., Zala, M., Keel, C., Boller, T., Amrhein, N., and Schmid, J. 1995. Temporally distinct accumulation of transcripts encoding enzymes of the prechorismate pathways in elicitor-treated, cultured tomato cells. Proc. Natl. Acad. Sci. U. S. A. 92:3166-3170.

Graham, J. S., Pearce, G., Merryweather, J., Titani, K., ERICSSON, L. H., and RYAN, C. A. 1985. Wound-induced proteinase inhibitors from tomato leaves. II. The cDNAdeduced primary structure of pre-inhibitor II. J. Biol. Chem. 260:6561-6564.

GU, Y. Q., ChaO, W. S., and WALling, L. L. 1996. Localization and post-translational processing of the wound-induced leucine aminopeptidase proteins of tomato. J. Biol. Chem. 271:25880 25887.

GuO, J., and WANG, M. H. 2009. Characterization of the phenylalanine ammonia-lyase gene (SlPAL5) from tomato (Solanum lycopersicum L.). Mol. Biol. Rep. 36:1579-1585.

Gusmão, M. R., Picanço, M. C., Guedes, R. N. C., Galvan, T. L., and PereirA, E. J. G. 2006. Economic injury level and sequential sampling plan for Bemisia tabaci in outdoor tomato. J. Appl. Entomol. 130:160-166.

Hebert, S. L., Jia, L. L., and Goggin, F. L. 2007. Quantitative differences in aphid virulence and foliar symptom development 
on tomato plants carrying the Mi resistance gene. Environ. Entomol. 36:458-467.

HeIL, M. 2010. Plastic defence expression in plants. Evol. Ecol. 24:555-569.

Hill, H. D., and StraKA, J. G. 1988. Protein determination using bicinchoninic acid in the presence of sulfhydryl reagents. Anal. Biochem. 170:203-208.

Howe, G. A., and JANDER, G. 2008. Plant immunity to insect herbivores. Annu. Rev. Plant Biol. 59:41-66.

Howe, G. A., Lightner, J., Browse, J., and Ryan, C. A. 1996. An octadecanoid pathway mutant (JL5) of tomato is compromised in signaling for defense against insect attack. Plant Cell 8:20672077.

InBAR, M., and GERLING, D. 2008. Plant-mediated interactions between whiteflies, herbivores, and natural enemies. Annu. Rev. Entomol. 53:431-448.

JEFFERSON, R. A. 1987. Assaying chimeric genes in plants: The GUS gene fusion system. Plant Mol. Biol. Rep. 5:387-405.

Jiang, Y. X., Nombela, G., and Muniz, M. 2001. Analysis by DCEPG of the resistance to Bemisia tabaci on an Mi-tomato line. Entomol. Exp. Appl. 99:295-302.

Jiménez, D. R., YoKomi, R. K., MAYER, R. T., and Shapiro, J. P. 1995. Cytology and physiology of silverleaf whitefly-induced squash silverleaf. Physiol. Mol. Plant Pathol. 46:227-242.

John, I., Hackett, R., CoOper, W., Drake, R., Farrell, A., and GRIERSON, D. 1997. Cloning and characterization of tomato leaf senescence-related cDNAs. Plant Mol. Biol. 33:641-651.

Kaloshian, I., Lange, W. H., and Williamson, V. M. 1995. An aphid-resistance locus is tightly linked to the nematode-resistance gene, Mi, in tomato. Proc. Natl. Acad. Sci. U. S. A. 92:622-625.

Kant, M. R., SABElis, M. W., HARING, M. A., and SCHUURINK, R. C. 2008. Intraspecific variation in a generalist herbivore accounts for differential induction and impact of host plant defences. Proc. Royal Soc. B 275:443-452.

Keinonen-Mettälä, K., Pappinen, A., and von Weissenberg, K. 1998. Comparisons of the efficiency of some promoters in silver birch (Betula pendula). Plant Cell Rep. 17:356-361.

Kempema, L. A., Cui, X., Holzer, F. M., and Walling, L. L. 2007. Arabidopsis transcriptome changes in response to phloemfeeding silverleaf whitefly nymphs. Similarities and distinctions in responses to aphids. Plant Physiol. 143:849-65.

Klingler, J., Powell, G., Thompson, G. A., and IsaAcs, R. 1998. Phloem specific aphid resistance in Cucumis melo line AR 5: effects on feeding behaviour and performance of Aphis gossypii. Entomol. Exper. Appl. 86:79-88.

Koornneef, A., and Pieterse, C. M. J. 2008. Cross talk in defense signaling. Plant Physiol. 146:839-844.

Koornneef, A., Leon-Reyes, A., Ritsema, T., Verhage, A., Den OtTer, F. C., van Loon, L. C., and Pieterse, C. M. J. 2008. Kinetics of salicylate-mediated suppression of jasmonate signaling reveal a role for redox modulation. Plant Physiol. 147:1358-1368.

Kosuge, S., Ohashi, Y., NaKajima, K., and Arai, Y. 1990. An improved assay for $\beta$-glucuronidase in transformed cells: methanol almost completely suppresses a putative endogenous $\beta$-glucuronidase activity. Plant Sci. 70:133-140.

Lapitan, N. L. V., Li, Y. C., Peng, J. H., and Botha, A. M. 2007. Fractionated extracts of Russian wheat aphid eliciting defense responses in wheat. J. Econ. Entomol. 100:990-999.

Lawrence, S. D., Novak, N. G., and Blackburn, M. B. 2007. Inhibition of proteinase inhibitor transcripts by Leptinotarsa decemlineata regurgitant in Solanum lycopersicum. J. Chem. Ecol. 33:1041-1048.

Le Hir, R., Beneteau, J., Bellini, C., Vilaine, F., and Dinant, S. 2008. Gene expression profiling: keys for investigating phloem functions. Trends Plant Sci. 13:273-280.
LeE, S. W., RobB, J., and NAZAR, R. N. 1992. Truncated phenylalanine ammonia-lyase expression in tomato (Lycopersicon esculentum). J. Biol. Chem. 267:11824-11830.

LeE, S. W., HeInZ, R., RobB, J., and NaZAR, R. N. 1994. Differential utilization of alternate initiation sites in a plant defense gene responding to environmental stimuli. Eur. J. Biochem. 226:109-114.

Lei, H., TJallingiI, W. F., and van Lenteren, J. C. 1998a. Probing and feeding characteristics of the greenhouse whitefly in association with host-plant acceptance and whitefly strains. Entomol. Exp. Appl. 88:73-80.

Lei, H., Xu, R., TuallingiI, W. F., and Van Lenteren, J. C. 1998b. Electrical penetration graphs of greenhouse whitefly, Trialeurodes vaporariorum (Westwood). Acta Entomol. Sin. 41:113-123.

Li, C. Y., Williams, M. M., LoH, Y. T., LeE, G. I., and Howe, G. A. 2002. Resistance of cultivated tomato to cell content-feeding herbivores is regulated by the octadecanoid-signaling pathway. Plant Physiol. 130:494-503.

Li, L., Zhao, Y. F., McCaig, B. C., Wingerd, B. A., Wang, J. H., Whalon, M. E., Pichersky, E., and Howe, G. A. 2004. The tomato homolog of CORONATINE-INSENSITIVE1 is required for the maternal control of seed maturation, jasmonate-signaled defense responses, and glandular trichome development. Plant Cell 16:126-143.

LiU, S. S., De BARRo, P. J., Xu, J., LuAn, J. B., ZaNG, L. S., RuAN, Y. M., and WAN, F. H. 2007. Asymmetric mating interactions drive widespread invasion and displacement in a whitefly. Science 318:1769-1772.

López, M. A., Bannenberg, G., and Castresana, C. 2008. Controlling hormone signaling is a plant and pathogen challenge for growth and survival. Curr. Opin. Plant Biol. 11:420-427.

Mantelin, S., Bhattarai, K. K., and Kaloshian, I. 2009. Ethylene contributes to potato aphid susceptibility in a compatible tomato host. New Phytol. 183:444-456.

Martin, J. H., and Mound, L. A. 2007. An annotated check list of the world's whiteflies (Insecta: Hemiptera : Aleyrodidae). Zootaxa 3-84.

Mayer, R. T., McCollum, T. G., McDonald, R. E., Polston, J. E., and Doostdar, H. 1996. Bemisia feeding induces pathogenesisrelated proteins in tomato, pp. 179-188, in D. Gerling and R. T. Mayer (eds.). Bemisia: 1995. Taxonomy, Biology, Damage, Control and Management. Intercept Ltd., Andover.

McGurl, B., Orozco-Cardenas, M., Pearce, G., and Ryan, C. A. 1994. Overexpression of the prosystemin gene in transgenic tomato plants generates a systemic signal that constitutively induces proteinase inhibitor synthesis. Proc. Natl. Acad. Sci. U. S. A. 91:9799-9802.

Miles, P. W. 1999. Aphid saliva. Biol. Rev. Camb. Philos. Soc. 74:41-85.

Mooney, K. A., HalitschKe, R., Kessler, A., and Agrawal, A. A. 2010. Evolutionary trade-offs in plants mediate the strength of trophic cascades. Science 327:1642-1644.

Moran, P., and ThOMPSON, G. 2001. Molecular responses to aphid feeding in Arabidopsis thaliana in relation to plant defense pathways. Plant Physiol. 125:1074-1084.

Mur, L. A. J., Kenton, P., AtZORn, R., Miersch, O., and Wasternack, C. 2006. The outcomes of concentration-specific interactions between salicylate and jasmonate signaling include synergy, antagonism, and oxidative stress leading to cell death. Plant Physiol. 140:249-262.

Musser, R. O., Hum-Musser, S. M., Eichenseer, H., Peiffer, M., ERvin, G., Murphy, J. B., and Felton, G. W. 2002. Herbivory: Caterpillar saliva beats plant defences-A new weapon emerges in the evolutionary arms race between plants and herbivores. Nature 416:599-600.

Mutti, N. S., Louis, J., Pappan, L. K., Pappan, K., Begum, K., Chen, M. S., Park, Y., Dittmer, N., Marshall, J., Reese, J. C., and REECK, G. R. 2008. A protein from the salivary glands of 
the pea aphid, Acyrthosiphon pisum, is essential in feeding on a host plant. Proc. Natl. Acad. Sci. U. S. A. 105:9965-9969.

Pautot, V., Holzer, F. M., and Walling, L. L. 1991. Differential expression of tomato proteinase inhibitor I and II genes during bacterial pathogen invasion and wounding. Mol. Plant-Microb. Interact. 4:284-292.

Pautot, V., Holzer, F. M., Reisch, B., and Walling, L. L. 1993. Leucine aminopeptidase: An inducible component of the defense response in Lycopersicon esculentum (tomato). Proc. Natl. Acad. Sci. U. S. A. 90:9906-9910.

Rep, M., DekKer, H. L., Vossen, J. H., De Boer, A. D., Houterman, P. M., Speijer, D., BAck, J. W., De Koster, C. G., and CORNELISSEN, B. J. C. 2002. Mass spectrometric identification of Isoforms of PR proteins in xylem sap of fungus-infected tomato. Plant Physiol. 130:904-917.

REYMOND, P., Weber, H., DAMOND, M., and FARMER, E. E. 2000. Differential gene expression in response to mechanical wounding and insect feeding in Arabidopsis. Plant Cell 12:707-719.

Rodriguez-SaOna, C., Crafts-Brandner, S. J., and CaÑas, L. A. 2003. Volatile emissions triggered by multiple herbivore damage: Beet armyworm and whitefly feeding on cotton plants. J. Chem. Ecol. 29:2539-2550.

SÁnchez-Hernández, C., LóPez, M. G., and DÉlano-Frier, J. P. 2006. Reduced levels of volatile emissions in jasmonate-deficient spr 2 tomato mutants favour oviposition by insect herbivores. Plant Cell Environ. 29:546-557.

Schuster, D. J., Mueller, T. F., Kring, J. B., and Price, J. F. 1990. Relationship of the sweetpotato whitefly to a new tomato fruit disorder in Florida. Hortscience 25:1618-1620.

SPOEL, S. H., and DONG, X. N. 2008. Making sense of hormone crosstalk during plant immune responses. Cell Host Microbe 3:348-351.

Sseruwagi, P., LegG, J. P., Maruthi, M. N., Colvin, J., Rey, M. E. C., and Brown, J. K. 2005. Genetic diversity of Bemisia tabaci (Gennadius) (Hemiptera : Aleyrodidae) populations and presence of the B biotype and a non-B biotype that can induce silverleaf symptoms in squash, in Uganda. Ann. Appl. Biol. 147:253-265.

Thaler, J. S., Fidantsef, A. L., and Bostock, R. M. 2002. Antagonism between jasmonate- and salicylate-mediated induced plant resistance: Effects of concentration and timing of elicitation on defense-related proteins, herbivore, and pathogen performance in tomato. J. Chem. Ecol. 28:1131-1159.

Thornburg, R. W., Kernan, A., and Molin, L. 1990. Chloramphenicol acetyltransferase (CAT) protein is expressed in transgenic tobacco in field tests following attack by insects. Plant Physiol. 92:500-505.

TJALLINGII, W. F. 2006. Salivary secretions by aphids interacting with proteins of phloem wound responses. J. Exp. Bot. 57:739-745.
VAn de Ven, W. T. G., Levesque, C. S., Perring, T. M., and WALLING, L. L. 2000. Local and systemic changes in squash gene expression in response to silverleaf whitefly feeding. Plant Cell 12:1409-1423.

van Kan, J. A. L., Joosten, M. H. A. J., Wagemakers, C. A. M., VAN DeN BerG-Velthuis, G. C. M., and DE Wit, P. J. G. M. 1992. Differential accumulation of messenger RNAs encoding extracellular and intracellular $P R$ proteins in tomato induced by virulent and avirulent races of Cladosporium fulvum. Plant Mol. Biol. 20:513-527.

VAn Kan, J. A. L., CoziJnsen, T., Danhash, N., and DE Wit, P. J. G. M. 1995. Induction of tomato stress protein mRNAs by ethephon, 2,6-dichloroisonicotinic acid and salicylate. Plant Mol. Biol. 27:1205-1213.

VAN Lenteren, J. C., and Noldus, L. P. J. J. 1990. Whitefly-plant relationships: Behavioural and ecological aspects, pp. 47-89, in D. Gerling (eds.). Whiteflies: Their Bionomics, Pest Status and Management. Intercept Ltd., Andover, UK.

VAn LoOn, L. C., ReP, M., and Pieterse, C. M. J. 2006. Significance of inducible defense-related proteins in infected plants. Аnnu. Rev. Phytopathol. 44:135-162.

WALling, L. L. 2008. Avoiding effective defenses: Strategies employed by phloem-feeding insects. Plant Physiol. 146:859866.

Walling, L. L. 2009. Adaptive defense responses to pathogens and pests. Adv. Bot. Res. 51:551-612.

Weinmann, P., Gossen, M., Hillen, W., Bujard, H., and Gatz, C. 1994. A chimeric transactivaror allows tetracycline-responsive gene expression in whole plants. Plant J. 5:559-569.

Will, T., TuallingiI, W. F., Thonnessen, A., and Van Bel, A. J. E. 2007. Molecular sabotage of plant defense by aphid saliva. Proc. Natl. Acad. Sci. U. S. A. 104:10536-10541.

WU, J. Q., and BALDWIN, I. T. 2009. Herbivory-induced signalling in plants: perception and action. Plant Cell Environ. 32:1161-1174.

Yoo, B. C., Aoki, K., Xiang, Y., Campbell, L. R., Hull, R. J., Xoconostle-CaZares, B., Monzer, J., Lee, J. Y., Ullman, D. E., and LUCAS, W. J. 2000. Characterization of Cucurbita maxima phloem serpin-1 (CmPS-1) - A developmentally regulated elastase inhibitor. J. Biol. Chem. 275:35122-35128.

Zarate, S. I., Kempema, L. A., and Walling, L. L. 2007. Silverleaf whitefly induces salicylic acid defenses and suppresses effectual jasmonic acid defenses. Plant Physiol. 143:866875.

Zhang, P. J., ZhENG, S. J., VAN LOON, J. J. A., BOLAND, W., DAVID, A., Mumm, R., and Dicke, M. 2009. Whiteflies interfere with indirect plant defense against spider mites in Lima bean. Proc. Natl. Acad. Sci. U. S. A. 106:21202-21207. 